\title{
A Conceptual Study on Contingent Impact of External Integration on Innovation Sme Business Success Relationship
}

\author{
Sheikh Muhamad Hizam Sheikh Khairuddin ${ }^{1}$, Zuhaib Hassan Qureshi ${ }^{1}$, Rosni Ab. Wahid ${ }^{1}$, Shehnaz Tehseen ${ }^{2}$, \\ Zulfiqar Hussain Pathan ${ }^{3} \&$ Mohammad Rafat Khan ${ }^{1}$ \\ ${ }^{1}$ Universiti Kuala Lumpur Business School (UniKL BIS), Universiti Kuala Lumpur, Malaysia \\ ${ }^{2}$ Sunway University Business School, Sunway University, Malaysia \\ ${ }^{3}$ School of Economics and Management, Beijing University of Posts and Telecommunication, China \\ Correspondence: Sheikh Muhamad Hizam Sheikh Khairuddin, Universiti Kuala Lumpur Business School (UniKL \\ BIS), Universiti Kuala Lumpur, Malaysia.
}

Received: April 30, 2019

doi:10.5430/ijfr.v10n5p370
Accepted: May 30, 2019

Online Published: June 11, 2019

URL: https://doi.org/10.5430/ijfr.v10n5p370

\begin{abstract}
It is widely acknowledged in the existing studies that innovation has the critical role in firms' performances. Moreover, it has been acknowledged that innovative activities are the main sources of growth, survivability, and success for SMEs firms. In the setting of entrepreneurship, earlier studies have claimed that innovation is the integrated element of entrepreneurship. However, the existing studies have also revealed inconsistent findings regarding the impacts of innovation on firm's performances under various contexts. Thus, this study claims that there should be a moderator to facilitate the relationship between innovations and firm's performances. Therefore, this study has introduced the external integration as a moderator to improve the relationship between types of innovations and firm's performances. The main objective of the study is to identify the relationship between various types of innovations including process innovation, product innovation, marketing innovation, and organizational innovations and business success operationalized with four dimensions including perceived financial performance, perceived non-financial performance, perceived business growth, and perceived performance relative to competitors) under the moderating role of external integration. Three theories namely Strategic Contingency Theory (SCT), Resource Dependence Theory (RDT), and Resource Based View (RBV) have been integrated to develop the proposed theoretical framework. The recent literature has been taken to gather the information about the variables that helped current study to develop a theoretical frame work and then eight propositions have been developed based on proposed theoretical framework. The external integration as a moderator between innovations and business success is the main theoretical contribution of this study. Furthermore, limitations have been stated at the end and recommendations have been made for future research.
\end{abstract}

Keywords: SMEs business success, innovations, Resource Based View (RBV), Strategic Contingency Theory (SCT), Resource Dependence Theory (RDT)

\section{Introduction}

The key intention of any business is to attain the greater success in its respective sector. However, due to limited resources, the SMEs are required to pay more attention on survival factors to achieve business success (Tehseen $e t$ al., 2018). SMEs play a major role in improving the economic growth of any nation (Omar et al., 2018). Since both internal and external factors are accountable for the superior performances of firms (Tehseen \& Sajilan, 2016). And innovation is one of the important internal factors that have been acknowledged broadly for the success of SMEs' performances. Earlier studies have recognized the influence of the types of innovations on SMEs' business success in different sectors (Bigliardi, 2013; Nwaobilor, Okoroji \& Anyanwu 2016). It has already been broadly mentioned that innovation plays a dynamic role in the business success. Innovation has been recognized as the most significant key factor in increasing the productivity and competitiveness of businesses. Consequently, it has become the key player in the success of businesses for all sectors.

Likewise, external integration has been considered as a vital external factor to achieve the superior firm's performance sand has been considered as a key moderating variable between entrepreneurial competencies and SMEs' business 
success relationship (Tehseen \& Ramayah, 2015). However, the deep understanding of innovation (process, product, marketing, and organizational) for SMEs business success is still limited specially, no study has been conducted so far by considering the moderating role of external integration for the relationship between innovation and SMEs' business success. Therefore, this study identifies the role of innovation in the of SMEs business success under the moderating influence of external integration. By reviewing the past literature on innovation, some studies have taken financial parameters as the basis of business success and to assess the performance of the firms (Matook, 2013). On the other hand, few researchers have focused on non-financial aspects (Haber \& Reichel, 2005; Hoque, 2004). Moreover, some studies have considered growth of company as the parameter of business success (Ahmad, 2007) and others have deemed performance relative to competitors as determinant factor for business success (Zakariaa et al., 2016; Nzimande \& Padayachee 2017).

This study has taken external integration as a moderator between independent and dependent variables. External integration indicates the extent to which the firms can build relationships with their customers and suppliers to structure their behaviours, procedures, organizational practices and strategies through collaborative processes in order to meet the customers' needs (Chen \& Paulraj, 2004). Three theories including; Resource Based View (RBV), Strategic Contingency Theory (SCT), and Resource Dependence Theory (RDT) have been integrated to support the theoretical framework of this study.

The next section provides the literature review regarding innovation, external integration, and SMEs' business success. While, the conclusion and future research are presented in the last section.

\section{Review of the Literature}

\subsection{Innovation and Its Importance}

The Innovation terminology was used for the very first time by the Austrian economist, Joseph Schumpeter in 1934. In his book, The Theory of Economic Development, Schumpeter claimed that entrepreneurs develop new products and technologies to make existing products and technologies obsolete overtime (Barringer \& Ireland, 2019).

Studies also argued that innovation plays a big role in the survival and success of firms (Jimenez \& Sanz-Valle, 2011) and for achieving long term competitive advantage (Standing \& Kiniti, 2011). Innovation specifies the adoption of new and improved processes, products, services, and organizational and marketing techniques (OECD, 2005).

SMEs are focusing on the continuous improvement in their business approach by doing the continuous innovation in their products and services to attain sustainability in the market. The global competitive market encourages improving their performances, capabilities, and competencies in the marketplace to distinguish themselves from the competitors. Furthermore, innovation is an important key factor in achieving high business growth, entering new markets and increasing market share and in attaining competitive advantage (Ceptureanu, 2015; Obadi, Kosir \& Korcek 2017).

Firms have started to recognize the value of innovation as a result of globalization; as such global competition has led to technological changes that have increased the importance of existing services and products. Innovation can be viewed as a business strategy because it creates valuable products and services and helps the organizations to improve their reputation.

Abundant literature is evident on the significant positive relationship between innovation and business success (Naranjo-Valencia et al., 2016). However, most of these studies have been carried out in several industries. For example, a study examined 446 multiple Spanish firms to determine the success ratio of innovation businesses (Naranjo-Valencia et al., 2015). There are many studies in the recent times that have proved the impact of different types of innovation on the business success. For instance, a study of Prajogo (2016) on 207 Australian manufacturing companies has revealed the business success due to the significant influence of product and process innovation.

\subsection{Concept of Innovation in Entrepreneurship}

The concept of innovation is widely used while defining entrepreneurship. According to Goosen (2007), entrepreneurs are the people who always search for new opportunities and implementation for their new business ideas. As mentioned earlier that Schumpeter had introduced the term innovation in which the concepts of market innovation, factor innovation, product innovation, process innovation, and event organizational innovation were involved (Syahida, 2008). The entrepreneurs who bring the entrepreneurial activities up to the high extent of establishing the company and then making it profitable through innovativeness and creativeness are referred as "Schumpeterian entrepreneurs" (Cuadrado-Roura \& Garcia-Tabuenca, 2008). Other researchers who have seen innovation in the context of entrepreneurship such as Hoselitz (1960) who claims innovation is a part of 
entrepreneurship, Dollinger (1995) considered it as a development of innovative economic institute, Rwigema and Venter (2004) recognised it as "the process of conceptualising, organising, launching, and nurturing a business opportunity into a potentially high growth venture in a complex, and unstable environment".

\subsection{Types of Innovation}

The innovation has been categorized into five forms; new production processes, new products, new markets, new resources and materials, and new organizational activities and events (Atalay et al., 2013). However, Brouwer (1991) has classified innovation into two main categories namely process and product innovations. In addition, Damanpour (1991) also proposed innovation as managerial innovations. In the same manner Higgins (1995) emphasized on marketing innovation and Huiban and Bouhsina (1998) stressed on organizational innovations.

Innovation has been classified as radical innovation and incremental innovation (Dewar and Dutton, 1986). Few researchers have also discriminated against technological innovations involving product and process innovations from non-technological innovations that relate to organizational and marketing innovations. According to Atalay et al. (2013), innovation is of four types namely process innovation, product innovation, marketing innovation, and organizational innovation, above four categories of innovations can be defined as follow:

\subsubsection{Process Innovation}

Process innovation refers to the introduction of better or new delivery or production methods. This kind of innovation involves major equipment or software and technical changes. For example, product development using computer aided methods, better or new technological devices to produce products and automate process customization.

\subsubsection{Product Innovation}

Product innovation is related to the introduction of new services or goods, or with a range of advanced features or service enhancements. It shows a significant improvement in technical specifications, materials and components, usability, embedded software or other functions such as quality materials with better functionality and so on.

\subsubsection{Marketing Innovation}

Marketing innovation means introducing new marketing approaches to make valuable changes in product design or packaging, prices, or product promotion, and product placement. Innovation marketing aims to better meeting customers' needs, entering new markets or positioning the products in the market to increase their sales. For example, significant changes to the furniture design are being introduced to create new looks and to attract customers.

\subsubsection{Organizational Innovation}

This innovation means using new methods within the business' practices of an organization. This indicates satisfaction with work that leads to high productivity, getting access to non-tradable assets or reduces supplies' costs through supply chain management.

\section{Business Success in SMEs}

Main visionary attribute for any size or type of organization is to put step ahead continuously on the ladder of success and particularly business type organizations are more emphatically conscious. The definition of business success is yet a contradictory concept because itcould be evaluated on various multi-dimensional parameters. Few scholars considered that financial parameters are pillars of success and are to be used to evaluate the performance of enterprises, however, other researchers also focused on non-finical elements. The evolutionary elements such as turnover, profitability ratio, and return on investments statistics were only used to measure the success of any enterprise (Brüderl \& Preisendörfer, 1998). However, Perren (2000) argued that only the financial indicators are not enough to evaluate the overall performance of any enterprise, because the non-financial elements are also very significant to assess the business success ratio of the organizations (Perren, 2000). Consequently, this study puts attention to conduct similar type of study, which is based on both parameters namely financial and non-financial measures along with business growth and performance relative to competitors. Moreover, several existing studies have only used subjective measures to measure business success or firm's performances under various contexts (Ahmad, 2007). This is because the SMEs are not accountable to disclose their financial data and that is why this is considered as a very sensitive issue for SMEs to reveal their financial performance (Ahmad, 2007; Wahid \& Mahmood, 2013). Thus, this study has also proposed using the subjective or perceived firm's performance measures. 


\subsection{Perceived Financial Performance}

Many studies have taken the financial measure as the most important indicator to assess the performance of the firms (Matook, 2013). According to Ahmad (2007), financial indicators comprise sales turnover, market share, profitability, and sales growth. Although, financial performance is massive and important variable for all organizations to empower financial growth, the organizations formulate and de-formulate their business strategies, by implementing new novel innovations, so that could obtain the competitive advantage and maximize the survival ratio. Financial growth is also affected by the growth of export, for example in China by the rapid technological development, export revenue was positively affected and it added value in economic growth (Timmer \& van Ark, 2005).

\subsection{Perceived Non-financial Performance}

The literature has revealed a variety of non-financial factors to measure the business success including the customer satisfaction which plays a vital part in the service sectors and manufacturing (Haber \& Reichel, 2005). According to Hoque (2004), employee satisfaction is also a critical non-financial indicator for business success. The customer retention is a key non-financial indicator as well which enhances the profitability and market share (Haber \& Reichel, 2005). One another research has added some non-financial performance indicators namely the social responsibility and lifestyle (Ahmad \& Seet, 2009). According to Ittner and Larcker (2003), it can be estimated that non-financial performance can assists the management of more effective strategies of the company. Non-financial performance imitates the area of intangible values considered by a firm and recognizes the benefits (Rahman et al., 2015; Ittner \& Larcker, 2003).

\subsection{Perceived Business Growth}

The growth specifies the success and failure of a business. Garnsey et al. (2006) stated that there are several internal and external factors which affect the business growth. Many empirical researches have taken growth rate to analyse the firm's performance (Ahmad, 2007). The performance is generally analyzed by the incensement in profits and/or growth in employees or sales. Similarly, employment or annual sales' growth of the company is the main factor to measure the business growth (Brinckmann, 2008). Although both elements can be analyzed by the objective figures and have been repeatedly utilized to assess the business growth. The growth is an comfortably measurable factor of business performance and more authentic than accounting assessments and other measures regarding the financial performance. Furthermore, business performance could be more valuable in the empirical research due to its multidimensional nature.

\subsection{Perceived Performance Relative to Competitors}

Companies are well alert about the actions of their competitors (Porter, 1990). Likewise, Brush and Vanderwerf (1992) argued that competitors' firms stay alert regarding the performance of new companies within industry. Thus, this awareness regarding rivals leads the firms towards competitive advantages and business success. There are empirical evidences in existing literature that prove that performance relative to competitors is also a key measurement of business success for SMEs (Ahmad, 2007; Bocij, 2018). Moreover, Zakariaa et al. (2016) have also used performance relative to competitors to access business success along with financial performance, non-financial performance, and business growth.

\section{External Integration}

Integration refers to the extent to which diverse groups collaborate effectively and work collectively to attain mutual goals). External integration refers to larger extent of operational competency whereby the products or services can be effortlessly accessible to clients to meet their requests through dissemination systems (Halley \& Beaulieu, 2009). In order to solve the business problems and improve operations, synchronized planning, working collaboratively, and information sharing among firms, suppliers and customers are basic themes of external integration. Moreover, external integration assists the firms to minimize the transaction costs by creating strong and relationships with key external parties. Koh et al. (2007) conducted study on SMEs of Turkey, a positive impact of strategic relationship of SMEs with their suppliers and customers was found on their performance. As mentioned earlier that organizational performance could be measured using both dimensions namely financial and non-financial measures. Ultimately, for each enterprise, the financial performance is very mandatory, but external collaborations positively effect on various parameters such as innovation performance (Demirbag et al., 2006; Brown, \& Ibekwe 2018).

\section{Impact of Innovation on SMEs' Business Success}

Murphy et al. (1996) suggested that the firms' success concept is a multidimensional, because an objective and subjective both indicators have been used to evaluate firm's performance (Harris, 2001). A success can be judged by 
its financial performance, non-financial performance, and business growth. Instead, a study suggested that financial and non-financial indicators complement each other and show the real performance of the company (Wiklund, 1999).

Cooper and Kleinschmidt (1991) emphasized the positive impact of high-level product innovations on the company's competitive advantage. Other studies have also provided empirical evidence in this respect (Mansury \& Love 2008). Another study by Hult et al. (2004) emphasizes that survival and entrepreneurship success are innovation-based. Other research focuses on innovative activities and on the importance of investing in research and development, because of its positive effects on survival, success, and business growth (Koellinger, 2008; Bosupeng, 2018).

In many studies, innovation has been used as a capability and is defined as a set of interrelated processes to facilitate product innovation and deployment (O'Cass \& Sok, 2012). It has been related to the excellent SMEs performance (Rosenbusch et al., 2011). For instance, according to Rosenbusch et al. (2011), SMEs achieve significant results and gain competitive advantage over their competitors due to their strong innovation capability. Although SMEs have limited resources (Terziovski, 2010), but they used to implement the innovative strategies (Rosenbusch et al., 2011). SMEs are small and flexible those allow new products to be delivered in market to meet consumers' needs (Sok et al., 2013; Bin-Zainudin, et.al., 2018). Instead, Rosenbusch et al. (2011) also revealed that the relationship between performance and innovation is contingent on the meta-analysis of the empirical results of previous researchers. They found that the operational relationship of innovation depends on many factors, for example the age, the cultural context, and the category of innovation of the company.

\section{Underpinning Theories and Development of Theoritical Framework}

In this study, three theories including Resource Based View (RBV), Strategic Contingency Theory (SCT), and Resource Dependence Theory (RDT) have been integrated to develop the proposed theoretical framework. According to RBV, the innovation can be considered as the unique, rare, valuable, inimitable, and non-substitutable internal resource that may lead towards the success of any business (Barney, 1991). However, since many researchers argued that only internal resources are not enough to attain the business success because external factors do contribute towards the success of any business as well. Thus the SCT first used by Hofer in 1975, has been also integrated while developing this study's framework. Based on this SCT, external integration could be considered as a significant external factor that could lead towards the business success as well.

Similarly, Resource Dependence Theory (RDT) introduced by Pfeffer and Salancik (1978) deliberates on the necessities of firm's resources. So, to obtain essential resources, the firms develop relationships with others (Nohria and Garcia-Pont, 1991; bin Abdul Razak \& Baharun 2018). Hence, RDT is involved with firm's demands to get optimum resources from other players within their vicinity and describes how enterprises sacrifice their resources in order to re-shape new alternative resources for better performance (Sherer \& Lee 2002; Basazinewu, 2018).

The innovation-business success relationship could be enhanced through external integration. In Figure 1, process innovation, product innovation, marketing innovation, and organizational innovation are taken as independent variables; external integration is taken as moderator; and business success operationalised with four dimensions including perceived financial performance, perceived non-financial performance, perceived business growth, and perceived performance relative to competitors, is taken as the dependent variable. The proposed theoretical framework is shown in Figure 1 and eight propositions have been developed based on the proposed theoretical framework. 


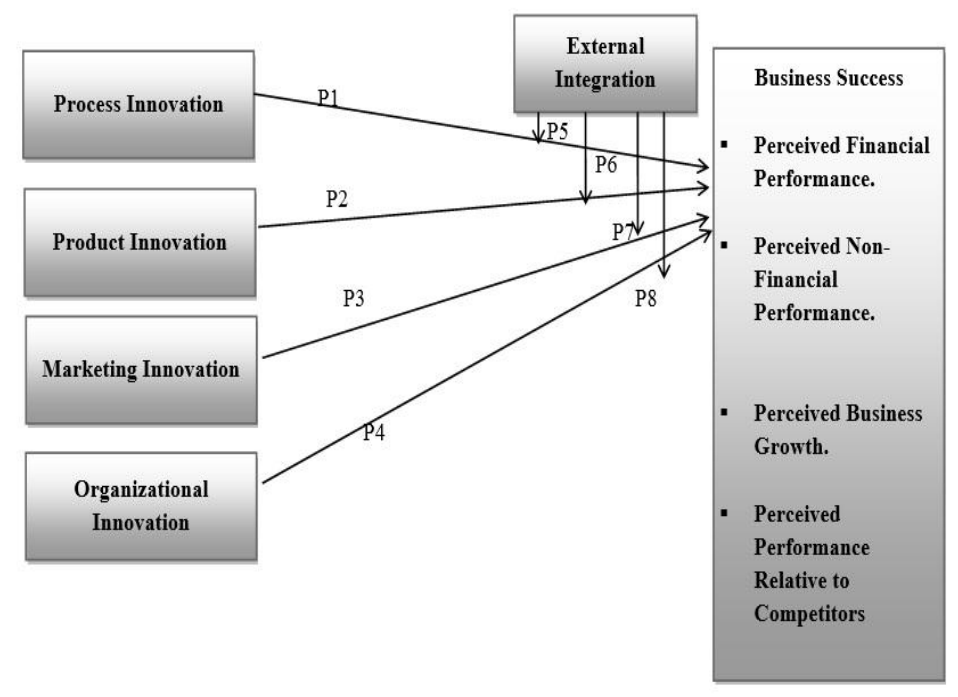

Figure 1. Conceptual framework

\section{Development of Propositions}

The eight propositions have been developed as follow:

\section{- Proposition1: Impact of Process Innovation on Business Success}

Process innovation usually occurs within the firms' internal practices and its antecedents and consequences related to product innovation (Reichstein \& Salter, 2006). Although, process and product innovations have a positive impact on business performance (Prajogo \& Ahmed, 2007), the understanding of the external market characteristics or conditions under which different forms of innovation are more or less beneficial is still limited (Prajogo, 2016). Based on above exiting studies, this study proposes the positive impact of process innovation on business success, thus,

P1: Process innovation positively impacts the business success of SMEs.

\section{- Proposition2: Impact of Product Innovation on Business Success}

Product innovation is explained as the use or development of new technologies, features, and components to produce new products. An extensive number of studies have focused on product innovation (Corsino \& Gabriele, 2010; Auzairy,et.al 2018), and studies have argued its direct impact on firms' business performance (Rauch et al., 2009; Tajeddini et al., 2006; Wiklund \& Shepherd, 2005). Based on above exiting studies, this study proposes the positive impact of product innovation on business success, thus,

P2: Product innovation positively impacts the business success of SMEs.

\section{- $\quad$ Proposition 3: Impact of Marketing Innovation on Business Success}

Marketing innovations constitute the new marketing techniques implementation for instance pricing of products and services, changes in product packaging and design, and product promotion (Naranjo-Valencia, 2015; Awoonor-Aziaku 2017). In order to achieve business success, firms are required to launch new goods and services in the market with high level of innovation (Atalay et al., 2013; Bakar, Abidin \& Haseeb 2015). Furthermore, marketing innovation assists businesses to fulfill customers' expectations which lead them towards the success (Cascio, 2011). Based on existing studies, this study also proposes positive influence of marketing innovation on business success, thus, the following proposition can be developed:

P3: Marketing innovation positively impacts the business success of SMEs.

\section{- $\quad$ Proposition 4: Impact of Organizational Innovation on Business Success}

Organizational innovation pushes the organizations to think innovatively about organizational challenges and find the solutions that can be considered as novel to organization and to the industry. According to Camisón and Villar-López (2014), OECD (2005) organizational innovation is the adoption of a new organizational technique in 
the workplace, business practices or external associations (this technique can be new administrative practice, new technology, new product or new service) to encourage the competitive advantage and improve the firm's performance.

Based on existing literature, it is proposed that there would be a positive influence of organizational innovation on business success. Therefore, the relevant proposition can be developed as follow:

P4: Organizational innovation positively impacts the business success of SMEs.

\section{- $\quad$ Proposition 5: Moderating Impact of External Integration on Innovation-Business Success Relationship}

External integration is the strong collaboration with suppliers and customers. With information sharing practices and mutual understanding, the businesses integrate with suppliers and customers. Supplier integration specifies to the business' connections with their suppliers for useful information sharing and association (Ragatz et al., 2002). While, according to Boon-itt and Pongpanarat (2011), the customer integration indicates to the instant reaction to meet customers' demands. Thus, the part of external integration for successful business is critical since it provides the important information and meets the customers' needs and requirements.

Since the above studies acknowledge the role of external integration in attaining the business success for SMEs, thus, the external integration could facilitate the innovation-business success relationship and therefore, this study proposes the following propositions:

P5: External integration positively moderates the impact of process innovation on business success.

P6: External integration positively moderates the impact of product innovation on business success.

P7: External integration positively moderates the impact of marketing innovation on business success.

P8: External integration positively moderates the impact of organizational innovation on business success.

\section{Discussion and Conclusion}

Innovation has been considered as one of the main critical internal resources for achieving the success of SMEs' businesses. There are four types of innovations that have been discussed in this study namely process innovation, product innovation, marketing innovation, and organizational innovation. The process innovation has been described as a new internal production and manufacturing process of an organization. While, product innovation is the process of introducing new and better products and services to the market. Whereas, the aim of marketing innovations is to address and fulfill the needs of customers through brining new promotions, product pricing, placement, product packaging to the market. On the other hand, the organizational innovation has been explained as the adoption of new behaviors within the organization. It involves the development of the administrative practices which result into high productivity and reducing the supplies costs through supply chain management, lean production, and business reengineering.

The main objective of this study was to develop a theoretical framework by integrating RBV, SCT, and RDT and then to develop eight propositions based on proposed theoretical framework. The main theoretical contribution of this study is that it has introduced external integration as a moderator in the relationship between different types of innovations and business success in the context of SMEs in general. However, the main limitation of this study is that it is only a conceptual study and did not conduct data analysis. Thus, to overcome this main limitation, the future studies are recommended to conduct the empirical research using this study's proposed theoretical framework under various context.

\section{References}

Ahmad, N. H. (2007). A cross cultural study of entrepreneurial competencies and entrepreneurial success in SMEs in Australia and Malaysia. Doctoral dissertation.

Ahmad, N. H., \& Seet, P. S. (2009). Understanding business success through the lens of SME founder-owners in Australia and Malaysia. International Journal of Entrepreneurial Venturing, 1(1), 72-87. https://doi.org/10.1504/IJEV.2009.023821

Atalay, M., Anafarta, N., \& Sarvan, F. (2013). The relationship between innovation and firm performance: An empirical evidence from Turkish automotive supplier industry. Procedia-Social and Behavioral Sciences, 75, 226-235. https://doi.org/10.1016/j.sbspro.2013.04.026

Auzairy, N. A., Mei, C. C., Min, C. S., \& Maulida, R. (2018). How Sustainable is the Foreign Direct Investment? In the Case of Malaysia. International Journal of Asian Social Science, 8(11), 1027-1038. 
https://doi.org/10.18488/journal.1.2018.811.1027.1038

Awoonor-Aziaku, L. (2017). Gender as a Social Construct in the Use of Dental Fricatives/ $/$ /and/d/in Ghanaian English. International Journal of English Language and Literature Studies, 6(3), 69-77. https://doi.org/10.18488/journal.23.2017.63.69.77

Bakar, N. A. A., Abidin, I. S. Z., \& Haseeb, M. (2015). Investigating exports performance between Malaysia and OIC member countries from 1997-2012. Asian Social Science, 11(7), 11. https://doi.org/10.5539/ass.v11n7p11

Barney, J. (1991). Firm resources and sustained competitive advantage. Journal of Management, 17(1), 99-120. https://doi.org/10.1177/014920639101700108

Barringer, B. R., \& Ireland, R. D. (2019). Entrepreneurship: Successfully Launching New Ventures (6th ed.). New Jersey: Pearson Prentice-Hall.

Basazinewu, Z. D. (2018). An Assessment Study on the Prevalence and Causes of Early Marriage and its Associated Problems on Socio-Economic and Health of Women in Gozamine Woreda East Gojjame Zone Amhara Region. International Journal of Social Sciences Perspectives, 2(1), 1-37. https://doi.org/10.33094/7.2017.2018.21.1.37

Bigliardi, B. (2013). The effect of innovation on financial performance: A research study involving SMEs. Innovation, 15(2), 245-255. https://doi.org/10.5172/impp.2013.15.2.245

Bin Abdul Razak, D., \& Baharun, F. N. B. (2018). Factors that Determine Customers Acceptance of Ar Rahn Financing in Selangor. International Journal of Asian Social Science, 8(11), 1017-1026. https://doi.org/10.18488/journal.1.2018.811.1017.1026

Bin-Zainudin, M. I., Bin-Ramdzan-Ali, A. A. E., Ahmad-Fadzil, A. S., Sarin, M. F., Binti-Ahmad-Zaki, N. A. S., Othman, A. K., \& Hassan, F. H. (2018). Halal Brand Personality and Brand Loyalty among Millenials Modest Fashion Consumers in Malaysia: A Conceptual Paper. International Journal of Asian Social Science, 8(11), 985-994. https://doi.org/10.18488/journal.1.2018.811.985.994

Bocij, P. (2018). OVIAR: Towards a Model for Cyberstalking Intervention and Reduction. International Journal of Emerging Trends in Social Sciences, 4(2), 58-66. https://doi.org/10.20448/2001.42.58.66

Boon-itt, S., \& Pongpanarat, C. (2011). Measuring service supply chain management processes: The application of the Q-sort technique. International Journal of Innovation, Management and Technology, 2(3), 217.

Bosupeng, M. (2018). Leading Indicators and Financial Crisis: A Multi-Sectoral Approach Using Signal Extraction. Journal of Empirical Studies, 5(1), 20-44. https://doi.org/10.18488/journal.66.2018.51.20.44

Brinckmann, J. (2008). Competence of top management teams and success of new technology-based firms. Gabler.

Brouwer, M. (1991). Schumpeterian Puzzles: Technological competition and economic evolution. University of Michigan Press. https://doi.org/10.3998/mpub.12939

Brown, E. D., \& Ibekwe, E. E. (2018). Effect of Institutional Factors on Foreign Direct Investment in Nigeria. The Economics and Finance Letters, 5(1), 12-27. https://doi.org/10.18488/journal.29.2018.51.12.27

Brüderl, J., \& Preisendörfer, P. (1998). Network support and the success of newly founded business. Small Business Economics, 10(3), 213-225. https://doi.org/10.1023/A:1007997102930

Brush, C. G., \& Vanderwerf, P. A. (1992). A comparison of methods and sources for obtaining estimates of new $\begin{array}{lllll}\text { venture performance. Journal of Business } & \text { 157-170. }\end{array}$ https://doi.org/10.1016/0883-9026(92)90010-O

Camisón, C., \& Villar-López, A. (2014). Organizational innovation as an enabler of technological innovation capabilities and firm performance. Journal of Business Research, 67(1), 2891-2902. https://doi.org/10.1016/j.jbusres.2012.06.004

Cascio, R. P. (2011). Marketing Innovation and Firm Performance Research Model, Research Hypotheses, And Managerial Implications.

Ceptureanu, E. G. (2015). New perspectives regarding change and innovation into Romanian SMEs. The Annals of The University of Oradea (p.1087).

Chen, I. J., \& Paulraj, A. (2004). Towards a theory of supply chain management: the constructs and measurements. Journal of Operations Management, 22(2), 119-150. https://doi.org/10.1016/j.jom.2003.12.007

Corsino, M., \& Gabriele, R. (2010). Product Innovation and Firm Growth: Evidence from the Integrated Circuit 
Industry. Industrial and Corporate Change, 20(1), 29-56. https://doi.org/10.1093/icc/dtq050

Cuadrado-Roura, J. R., \& Garcia-Tabuenca, A. (2008). Innovative and creative entrepreneurship in Spain. International Journal of Foresight and Innovation Policy, 5(1-3), 113-135. https://doi.org/10.1504/IJFIP.2009.022101

Damanpour, F. (1991). Organizational Innovation: A Meta-analysis of Effects of Determinants and Moderators. The Academy of Management Journal, 34(3), 555-590. https://doi.org/10.5465/256406

Demirbag, M., Lenny Koh, S. C., Tatoglu, E., \& Zaim, S. (2006). TQM and Market Orientation's Impact on SMEs' Performance. Industrial Management \& Data Systems, 106(8), 1206-1228. https://doi.org/10.1108/02635570610710836

Dewar, R. D., \& Dutton, J. E. (1986). The Adoption of Radical and Incremental Innovations: An Emprical Analysis. Management Science, 32, 1422-1433. https://doi.org/10.1287/mnsc.32.11.1422

Dollinger, M. (1995). Entrepreneurship: Strategies and Resources. Illinois: Irwin.

Garnsey, E., Stam, E., \& Heffernan, P. (2006). New Firm Growth: Exploring Processes and Paths. Industry and Innovation, 13(1), 1-20. https://doi.org/10.1080/13662710500513367

Goossen, R. J. (2007). Entrepreneurial Excellence. NJ: Career Press.

Haber, S., \& Reichel, A. (2005). Identifying Performance Measures of Small Ventures-the Case of the Tourism Industry.Journal of Small Business Management, 43(3), 257-286. https://doi.org/10.1111/j.1540-627X.2005.00137.x

Halley, A., \& Beaulieu, M. (2009). Mastery of Operational Competencies in The Context of Supply Chain Management. Supply Chain Management: An International Journal, 14(1), 49-63. https://doi.org/10.1108/13598540910927304

Harris, L. C. (2001). Market Orientation and Performance: Objective and Subjective Empirical Evidence from UK Companies. Journal of Management Studies, 38(1), 17-43. https://doi.org/10.1111/1467-6486.00226

Higgins, J. M. (1995). Innovation: The Core Competence. Strategy \& Leadership, 23(6), 32-36. https://doi.org/10.1108/eb054532

Hoque, Z. (2004). A Contingency Model of the Association between Strategy, Environmental Uncertainty and Performance Measurement: Impact on Organisational Performance. International Business Review, 13(4), 485-502. https://doi.org/10.1016/j.ibusrev.2004.04.003

Hoselitz, B. R. (1960). Entrepreneurship and Economic Growth. Sociological Aspects of Economic Growth, 139-158.

Huiban, J. P., \& Bouhsina, Z. (1998). Innovation and the Quality of LabourFctor: An Empirical Investigation in The French Food Industry. Small Business Economics, 10(4), 389-400. https://doi.org/10.1023/A:1007967415716

Hult, G. T. M., Hurley, R. F., \& Knight, G. A. (2004). Innovativeness: Its Antecedents and Impact on Business

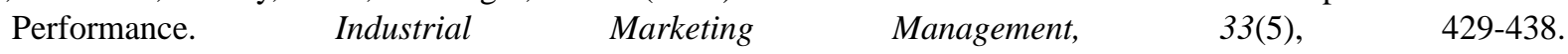
https://doi.org/10.1016/j.indmarman.2003.08.015

Ittner, C. D., \& Larcker, D. F. (2003). Coming Up Short on Nonfinancial Performance Measurement. Harvard Business Review, 81(11), 88-95.

Jimenez, J. D., \& Sanz-Valle, R. (2011). Innovation, Organizational Learning and Performance. Journal of Business Research, 64(4), 408-417. https://doi.org/10.1016/j.jbusres.2010.09.010

Koellinger, P. (2008). The Relationship between Technology, Innovation, and Firm Performance - Empirical Evidence from E-business in Europe. Research Policy, 37, 1317-1328. https://doi.org/10.1016/j.respol.2008.04.024

Koh, S., Demirbag, M., Bayraktar, E., Tatoglu, E., \& Zaim, S. (2007). The Impact of Supply Chain Management Practices on Performance of SMEs. Industrial Management \& Data Systems, 107(1), 103-24. https://doi.org/10.1108/02635570710719089

Mansury, M. A., \& Love, J. H. (2008). Innovation, Productivity and Growth in US Business Services: A Firm-Level Analysis. Technovation, 28, 52-62. https://doi.org/10.1016/j.technovation.2007.06.002

Matook, S. (2013). Measuring the Performance of Electronic Marketplaces: An External Goal Approach Study. Decision Support Systems, 54(2), 1065-1075. https://doi.org/10.1016/j.dss.2012.10.032 
Murphy, G. B., Trailer, J. W., \& Hill, R. C. (1996). Measuring Performance in Entrepreneurship Research. Journal of Business Venturing, 36(1), 15-23. https://doi.org/10.1016/0148-2963(95)00159-X

Naranjo-Valencia, J. C., Jiménez-Jiménez, D., \& Sanz-Valle, R. (2016). Studying the Links between Organisational Culture. Innovation and Performance in Spanish Companies.RevistaLatinoamericana De Psicología, 48(1), 30-41. https://doi.org/10.1016/j.rlp.2015.09.009

Nohria, N., \& Garcia-Pont, C. (1991). Global Strategic Linkages and Industry Structure. Strategic Management Journal, 12(S1), 105-124. https://doi.org/10.1002/smj.4250120909

Nwaobilor, C. A., Okoroji, L., \& Anyanwu, J. O. (2016). Assessing the Role of Motivation in Organisational Development a Study of National Assembly, Abuja. International Journal of Economics, Business and Management Studies, 3(2), 82-93.

Nzimande, N., \& Padayachee, P. (2017). Evaluation of the current procurement planning process in a district municipality. International Journal of Public Policy and Administration Research, 4(1), 19-34. https://doi.org/10.18488/journal.74.2017.41.19.34

O'Cass, A., \& Sok, P. (2012). Examining the Role of Within and between Functional Area.

Obadi, S., Kosir, I., \& Korcek, M. (2017). The Impact of Low Oil Prices on the Trade Balance of Balkan Countries and their Energy Security. Energy Economics Letters, 4(3), 20-27. https://doi.org/10.18488/journal.82.2017.43.20.27

OECD. (2005). The Measurement of Scientific and Technological Activities Oslo Manual. Guidelines for Collecting and Interpreting Innovation Data (3rd ed.). Paris: OECD EUROSTAT. https://doi.org/10.1787/9789264013100-en

Omar, F. I., Dimyati, H. A., Ahmad, N., \& Khairuddin, S. M. H. S. (2018). Digital Inclusion Among Entrepreneurs of Small and Medium Enterprises (SMEs): A Preliminary Survey. Journal of Education and Social Science, 9(2), 90-97.

Perren, L. (2000). Factors in the Growth of Micro-enterprises (part 2): Exploring the Implications. Journal of Small Business and Enterprise Development, 7(1), 58-68. https://doi.org/10.1108/EUM0000000006805

Pfeffer, J., \& Salancik, G. R. (1978). The External Control of Organisations. New York.

Porter, M. E. (1980). Competitive Strategy: Techniques for Analyzing Industries and Competitors. New York: free Press.

Prajogo, D. I. (2016). The Strategic Fit between Innovation Strategies and Business Environment in Delivering Business Performance. International Journal ofProduction Economics, 171, 241-249. https://doi.org/10.1016/j.ijpe.2015.07.037

Prajogo, D. I., \& Ahmed, P. K. (2007). The Relationships between Quality, Innovation and Business Performance: An Empirical Study. International Journal of Business Performance Management, 9(4), 380-405. https://doi.org/10.1504/IJBPM.2007.013361

Ragatz, G. L., Handfield, R. B., \& Petersen, K. J. (2002). Benefits Associated with Supplier Integration into New Product Development under Conditions of Technology Uncertainty. Journal of Business Research, 55(5), 389-400. https://doi.org/10.1016/S0148-2963(00)00158-2

Rahman, S. A., Ahmad, N. A., \& Taghizadeh, S. K. (2015). Entrepreneurial Competencies of the BoP Entrepreneurs in Achieving Business Success: A Study on the Mom and Pop Shops in Urban Cities of Bangladesh. Proceedings of 11th Asian Academy of Management International Conference (AAMC 2015) (pp. 1552-1563).

Rauch, A., Wiklund, J., Lumpkin, G. T., \& Frese, M. (2009). Entrepreneurial Orientation and Business Performance: An Assessment of Past Research and Suggestions for the Future. Entrepreneurship Theory and Practice, 33(3), 761-787. https://doi.org/10.1111/j.1540-6520.2009.00308.x

Reichstein, T., \& Salter, A. (2006). Investigating the Sources of Process Innovation among UK Manufacturing Firms. Industrial and Corporate Change, 15(4), 653-682. https://doi.org/10.1093/icc/dt1014

Rosenbusch, N., Brinckmann, J., \& Bausch, A. (2011). Is Innovation Always Beneficial? A Meta-analysis of the Relationship between Innovation and Performance in SMEs. Journal of Business Venturing, 26, 441-457. https://doi.org/10.1016/j.jbusvent.2009.12.002

Rwigema, H., \& Venter, R. (2004). Advanced Entrepreneurship. Cape Town: Oxford University Press. 
Schumpeter, J. A. (1934). The Theory of Economic Development: An Inquiry into Profits, Capital, Credit and the Business Cycle. New York: Transaction Publishers.

Sherer, P. D., \& Lee, K. (2002). Institutional Change in Large Law Firms: A Resource Dependency and Institutional Perspective. Academy of Management Journal, 45(1), 102-119. https://doi.org/10.2307/3069287

Sok, P., O'Cass, A., \& Sok, K. M. (2013). Achieving Superior SME Performance: Overarching Role of Marketing, Innovation, and Learning Capabilities. Australasian Marketing Journal (AMJ), 21(3), 161-167. https://doi.org/10.1016/j.ausmj.2013.04.001

Standing, C., \& Kiniti, S. (2011). How can Organizations Use Wikis for Innovation?. Technovation, 31, 287-295. https://doi.org/10.1016/j.technovation.2011.02.005

Syahida, A. (2008). Technology Entrepreneurship Development in Malaysia: A Case Study of the National Automotive Industry (PhD). Kuala Lumpur: Universiti Malaya.

Tajeddini, K., Trueman, M., \& Larsen, G. (2006). Examining the Effect of Market Orientation on Innovativeness. Journal of Marketing Management, 22(5-6), 529-551. https://doi.org/10.1362/026725706777978640

Tehseen, S., \& Ramayah, T. (2015). Entrepreneurial Competencies and SMEs Business Success: The Contingent Role of External Integration. Mediterranean Journal of Social Sciences, 6(1), 50-61. https://doi.org/10.5901/mjss.2015.v6n1p50

Tehseen, S., \& Sajilan, S. (2016). Impact of Innovative Practices on Business Growth Under The Moderating Impacts of Culture-A Conceptual Model. Review of Integrative Business and Economics Research, 5(2), 28-46.

Tehseen, S., Qureshi, Z. H., \& Ramayah, T. (2018). Impact of Network Competence on Firm's Performances Among Chinese and Indian Entrepreneurs: A Multigroup Analysis. International Journal of Entrepreneurship, 22(2), 1-14.

Terziovski, M. (2010). Innovation Practise and its Performance Implications in Small and Medium Enterprises (SMEs) in the Manufacturing Sector: A Resource-Based View. Strategic Management Journal, 31(8), 892-902. https://doi.org/10.1002/smj.841

Timmer, M. P., \& Van Ark, B. (2005). Does Information and Communication Technology Drive EU-US Productivity Growth Differentials?. Oxford Economic Papers, 57(4), 693-716. https://doi.org/10.1093/oep/gpi032

Wahid, R. A., \& Mahmood, R. (2013). Relationship of Intellectual Capital Dimensions and Performance of Banks in Malaysia: An Exploratory Study. International Journal of Business and Social Science, 4(15), 151-159.

Wiklund, J. (1999). The Sustainability of the Entrepreneurial Orientation Performance Relationship. Entrepreneurship Theory \& Practice, 24, 37-48. https://doi.org/10.1177/104225879902400103

Wiklund, J., \& Shepherd, D. (2005). Entrepreneurial Orientation and Small Business Performance: A Configurational Approach. Journal of Business Venturing, 20(1), 71-91. https://doi.org/10.1016/j.jbusvent.2004.01.001

Zakariaa, N., Abdullaha, N. A. C., \& Yusoffa, R. Z. (2016). The Innovation-Performance Linkage: Empirical Evidence of Malaysian Manufacturing SMEs. ISSC 2016: International Soft Science Conference. The European proceedings of Social and Behavioural Sciences (EpSBS) (pp. 419-424). https://doi.org/10.15405/epsbs.2016.08.59 